\title{
Preventive Detention in Counter-insurgencies: The Case of Kashmir
}

\author{
MOHMAD AABID BHAT*
}

\begin{abstract}
This paper offers an analysis of preventive detention in the context of the disputed territory of Jammu and Kashmir. It primarily explores the covert objectives behind the use of a preventive detention law, namely the Public Safety Act in Kashmir. It explains how this law has been used as a political tool by authorities to achieve their ulterior motives, which diverge from the philosophy of detention, i.e. the rehabilitation of the prisoners. This paper seeks to answer two main questions: firstly, why is preventive detention being used abusively in Kashmir, and secondly, how and why has it persisted despite widespread condemnation and accusations of human rights abuse.
\end{abstract}

\section{Introduction}

$\mathrm{T}$ he disputed territory of Jammu and Kashmir (J\&K) has been engulfed in a protracted armed conflict between two nuclear powers -India and Pakistan- for the past seven decades. The part under Indian administration is called Indian Administered Kashmir (IAK), and the part under Pakistani administration is called Pakistan Administered Kashmir (PAK). The conflict took a serious turn in 1989, with the rise of an armed insurgency in IAK. The insurgency went through various ebbs and flows, and the Indian state actively sought to contain this insurgency at many levels. The
Indian administration tried to delimit the sphere of armed insurgents believed to be sent from Pakistan. Dhakal categorizes the counterinsurgency (COIN) campaign launched by India in the disputed territory of Jammu and Kashmir into two distinct phases, from 1989 to 2000 (Phase I), and 2000 onwards (Phase II). ${ }^{1}$ Phase I involved the iron-fist approach, which was militaristic in nature. India's iron-fist approach is evident in the military operations that were in place, namely the operations Shayak, ${ }^{2}$ Vijay and Eraze, ${ }^{3}$ and Parakram. ${ }^{4}$ However, these militarist tactics could not annihilate the core of the insurgency. Therefore, a shift towards a mixed approach of COIN
* Jamia Millia Islamia, India 2019, pp. 53-68 


\section{The Indian government}

\section{resorted to harsh tactics to}

control the public outcry.

The methods employed were

\section{numerous and diverse}

has lately been observed. This approach includes Winning Hearts and Minds (WHAM) along with the militaristic operations.

David Galula, a counterinsurgency theorist, emphasizes the role of the civilian population as an inseparable element in any COIN campaign. ${ }^{5}$ He argues that the success of COIN operations depends upon weakening the bond between the insurgents and the local people, thus deterring civilians from supporting the insurgency. As far as the case of Kashmir is concerned, the support of people to insurgents and insurgency did not wane, which could be recognized from the high level of support ${ }^{6}$ insurgents received from the population. In Phase II of the insurgency, a noticeable decrease in the involvement of armed rebels, but an increase in the involvement of civilians, assuming the form of a 'total insurgency' of the entire population, was seen. ${ }^{7}$

In order to understand this transformation, the background of the conflict, and the Indian state's responses to the insurgency, which aimed to limit the involvement of the civilian population, should be considered. As mentioned above, several mili- tary operations were implemented to annihilate the armed insurgents and to instill fear among the population to keep them from supporting the insurgents. These militaristic operations reduced the number of armed insurgents considerably. Consequent to this, the WHAM approach was utilized to further detach the population from supporting the insurgency. An environment of free and fair elections was emphasized. In the early 2000 s resistance was at its lowest point, and remained so until 2008, when the illegal transfer of land to the Shri Amarnath Shrine Board (SASB) evoked widespread public condemnation, including massive civilian protests against the perceived political intent of this act. ${ }^{8}$ Objections to the illegal transfer of land ${ }^{9}$ united the people, and strengthened their efforts to oppose any idea of changing the demography of the state of Jammu and Kashmir.

The Indian government resorted to harsh tactics to control the public outcry. The methods employed were numerous and diverse. Recognizing the changing nature of the insurgency in Kashmir -from diminished armed resistance to an increase in unarmed civilian resistance- the state maneuvered its tactics to gain control over the civilian population participating in the resistance movement. One such tactic involved detaining people under a preventive detention law, the Jammu and Kashmir Public Safety Act (PSA).

This paper explores the possible psychological rationale behind the 


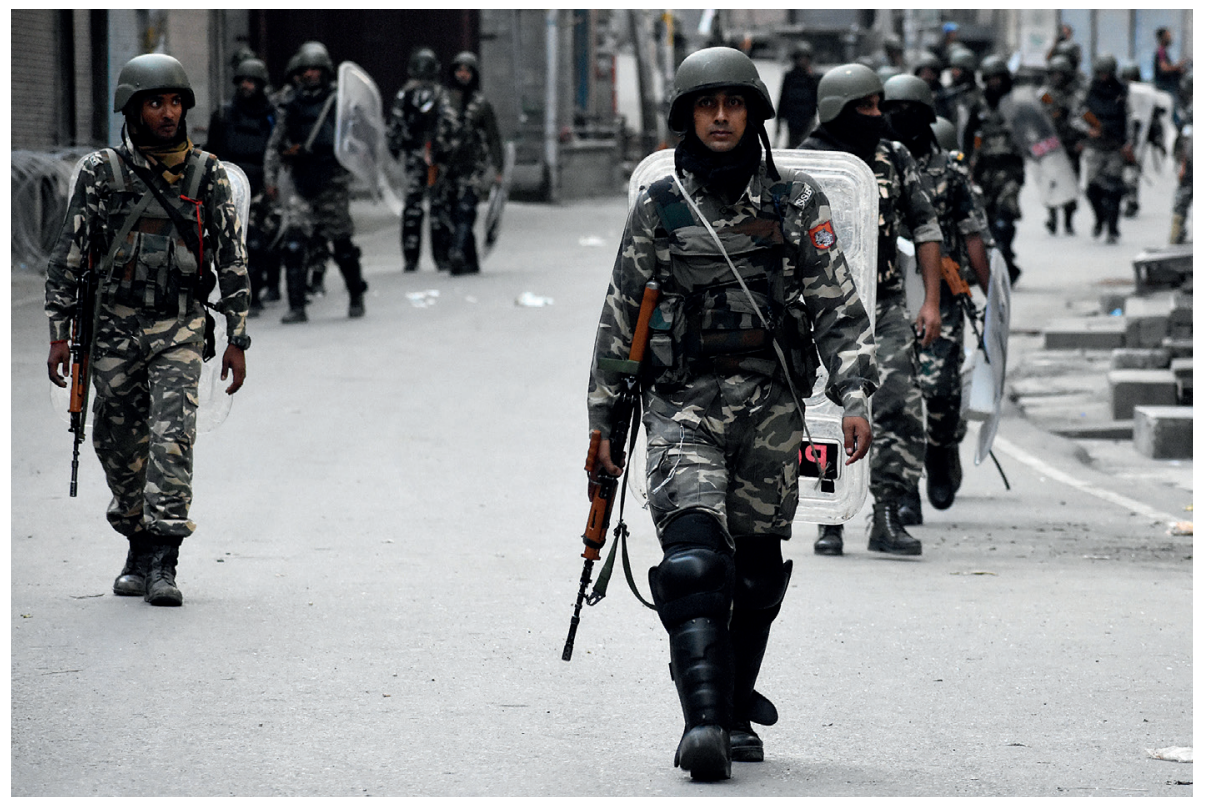

Indian paramilitary soldiers patrol on a street during a curfew in Srinagar, Kashmir on August 8, 2019, after the Indian government has suspended internet and schools and colleges across the Kashmir valley. FAISAL KHAN / AA Photo

Indian state's excessive use of preventive detention law. This study utilizes Michel Foucault's concept of dispositif in the context of the disputed territory of Kashmir to establish a relation with the state's psychological rationale. Dispositif refers to the institutional, physical, and administrative maneuvers by the authority in such a way to be used for their own purpose (i.e. to enhance the control and power). Lastly, it utilizes framing theory to explore the method that the hegemonic state uses to contain the psyche of the Kashmiri population as another form of thought control.

\section{History of Preventive Detention Law in Kashmir}

The roots of the PSA can be traced back to the Public Security Act, which was implemented in 1946 in colonial Kashmir to put the members of the Quit Kashmir Movement under preventive detention. It was later replaced by the Preventive Detention Act of 1954, which was a temporary provision only intended for a duration of five years. However, prior to its expiration, it was amended and replaced by the Preventive Detention Act of 1958. This Act underwent a series of amendments until the enactment of the Jammu and Kashmir Public Safety Ordinance in 1977 by Sheikh Abdullah, then Chief Minister. A few months later, in 1978, this ordinance was transformed into the Public Safety Act. ${ }^{10}$

The latest PSA, promulgated in 1978, provides for the administrative detention of a person without trial for a maximum of two years for acting against the "security of the state," and for a period of one year for a person 
"acting in any manner prejudicial to the maintenance of public order." 11 However, further amendments were made in 2012 which allowed for the maximum time period in the former case to be substituted by "six months," which may be extended up to two years. Also, in the latter, the time period was substituted with "three months," which may be extended to twelve months. The deputy commissioner or the district magistrate is the executive authority who maintains the power either to reject or to accept the recommendations submitted by the police.

The rationale of the PSA, as acclaimed by Sheikh Abdullah, was to book timber smugglers under this Act in order to protect the forest ecosystem; but the covert political motives came to the fore when the Act was invoked for the first time to achieve political gains. Ghulam Nabi Patel, President of Kashmir Motors Drivers Association (KMDA), had supported the Janatha Party against the National Conference Party in the state elections of 1977 and was subsequently incarcerated under the PSA by the Abdullah government. Eventually, this legacy was adopted by successive regimes, which detained members of Jamat-i-Islami, a religious and sociopolitical organization in Jammu and Kashmir, to clear the political opposition. ${ }^{12}$

Similarly, in 2008, the state administration resorted to this Act and invoked it against the civilians who protested in the backdrop of the "Shopian rape case" and the "Machil fake encounter." Since then, this law has continued to be grossly abused. It has become the norm to detain civilians under this Act, which can be seen in its indiscriminate use by the successive governments in power. The Act has become a disempowering and coercive instrument of the state, utilized to indiscriminately target political opponents -or whoever the authorities wish to target.

\section{Law and Counterinsurgency: Indiscriminate Usage of the PSA in Kashmir}

Muni explains the various strategies used for counterinsurgency. ${ }^{13} \mathrm{He}$ argues that one strategy is to utilize various legislations to reduce the sphere of the insurgents. This strategy has been utilized in the recent past in Jammu and Kashmir against the backdrop of the uprising in 2008 . The indiscriminate use of the PSA by the state administration is evident from its ever-increasing statistics. Measuring the scale of preventive detention in Kashmir, it was found that J\&K prisons contained 11.5 percent of such detentions in 2008 alone, 14 times higher than the national average. ${ }^{14}$ In a reply to the request seeking information of detainees under the Right to Information Act (RTI), the state's Home Department acknowledges 16,329 cases of PSA registered since $1988 .{ }^{15}$ The Kashmir Bar Association contests this figure, giving an estimate of 40,000 cases of PSA registered since 1989 . These numbers remain contested. In another RTI request filed by JKCCS, a civil soci- 
ety group based in Srinagar, Kashmir, seeking information regarding the cases involving the PSA, information on only 5,597 cases was provided. This all proves that major discrepancies exist in sharing basic information concerning those affected by the PSA. Moreover, it shows the authorities' lack of seriousness and lack of accountability toward maintaining accurate information regarding such cases. The incredible increase in the number of cases became conspicuously evident during the subsequent years of the uprising. Amnesty International revealed in their 2011 report that J\&K Home Department had provided details of 334 persons booked under the PSA in the short span between January 5, 2010 and February 14, 2010. ${ }^{16}$ A 2012 estimate by the Economic Times reports 617 cases of PSA in 2010 alone. ${ }^{17}$

The cycle of arrests has continued. After the killing of Militant Commander Burhan Wani in 2016, the government put serious restrictions on the movement of people, even disallowing them to participate in funeral prayers for loved ones. The very next day police and paramilitary forces resorted to killing about 17 civilians. The protests took the shape of a full-blown uprising. In order to limit its sphere, about 660 persons were detained under the PSA in 2016 and reports estimated about 360 cases of preventive detentions in 2017. ${ }^{18}$ The disproportionate use of this law found a mention in the report documented by a three member team of interlocutors sent to Kashmir by the Indian government

\section{The objective of annihilating} the resistance is achieved through a strategy of perpetual imprisonment, which aims to transform the resistance into obedience and docility

to monitor the ground situation in 2011 and the recent exhaustive report by the United Nations Office of Commissioner for Human Rights (OCHR) in 2018.

In 2019, the PSA was used in the aftermath of the attack on the Central Reserve Police Force (CRPF) which killed 40 personnel. 500 arrests were made in response, including members of Jamat-i-Islami, the Hurriyat conference, and the Jammu Kashmir Liberation Front (JKLF). ${ }^{19}$ In addition to this law, the Unlawful Activities Prevention Act (UAPA) was utilized to ban certain sociopolitical organizations such as Jamat-i-Islami and the JKLF. Use of the PSA was not confined to the Jamat-i-Islami activists alone, but was extended to their families as well, as the children of activists were also booked under this law. ${ }^{20}$

Analyzing its indiscriminate usage, it can be said that the utilization of the PSA has been so arbitrary that it violates its own constitutional mandate. Although it was made clear in the amendment of 2012 that children 


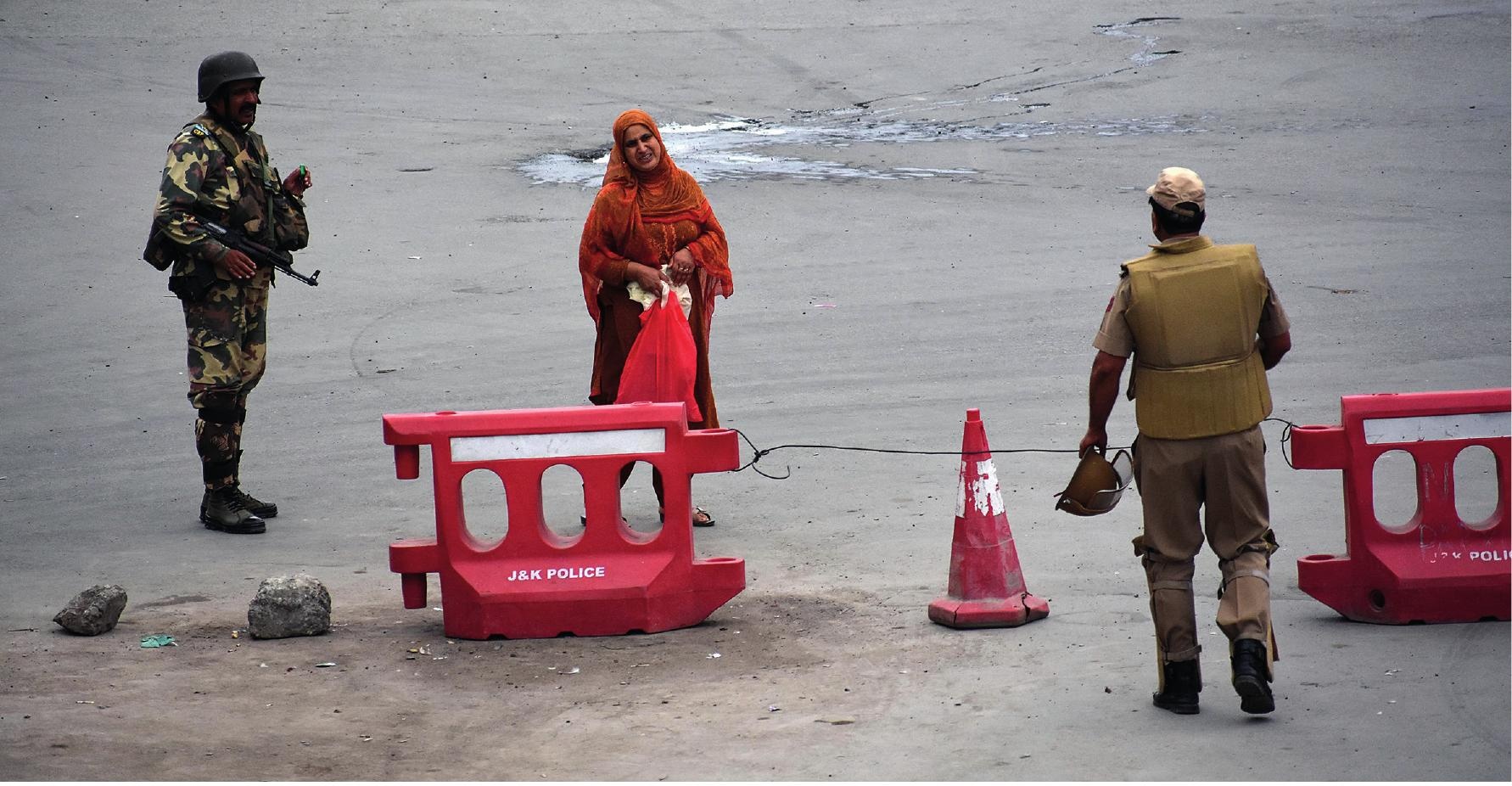

A Kashmiri

woman requests

passage during

a curfew in

Srinagar,

Kashmir, India

on August 6,

2019.

FAISAL KHAN / AA Photo

should not be detained under the PSA, this clause has been markedly violated. Babbar Qadri, a lawyer who challenges cases of the PSA in court, estimates the number of children detained under the PSA at more than $1,000 .^{21}$

In fact, there are several cases of Indian authorities arresting children and falsely writing down their age. In 2010, Sheikh Akram, Harris Rasheed, Omar Maqbool, and Mushtaq Ahmad were booked under the PSA. In 2011, Mohsin Majeed Shah and Burhan Nazir were booked under the PSA. ${ }^{22}$ Rayees Ahmad Mir was listed as 18 in the police dossier and booked under the PSA in 2016. Similarly, Tariq Ahmad, who was falsely identified as 21 years old and lodged in Kathua Jail in Jammu, met the same fate. Zubair was listed as 22 years old despite being a minor. ${ }^{23}$ Adding to the list, another Kashmiri minor named Tanveer Ahmad was booked under the Act in 2016. ${ }^{24}$ Faizan Rafeeq Hakeem, booked under the PSA, received international attention after being highlighted by the Amnesty International. A fact-finding team of Indians has recently been to the Kashmir valley and returned with the horrifying figure that up to 13,000 men and boys had been arrested. ${ }^{25}$ This practice, therefore, is deeply embedded in the Indian military strategy to wipe out future generations of the uprising.

Even more troubling, the extreme nature of state violence can be realized through a case in which a physically challenged Kashmiri was booked under the PSA for allegations of stone throwing. ${ }^{26}$ Not officially recognizing its indiscriminate use and harmful consequences, the state administration showed a lack of political will to revoke the Act, as seen in the state- 
ment of then Chief Minister, who claimed that there was no need to revoke the Act. $^{27}$

Ironically, the PSA is now being used against those who were responsible for bringing it into force, and who have long supported it. Farooq Abdullah, the former Chief Minister of the state of Jammu and Kashmir, who did not identify himself with resistance politics and who has been a loyal ally of the Indian government in Kashmir, was detained under the Act in the context of the de-operationalization of Article 370 on August 5, 2019. This Article had guaranteed a special status to Jammu and Kashmir, providing it the right to have its own constitution and the power to make laws on all matters except for defense, communications, and foreign affairs. This specific Article rendered the Indian Constitution in the state of Jammu and Kashmir non-applicable. The Indian Parliament's unilateral decision to abrogate Article 370 is considered illegal by legal luminaries and human rights activists. As a result, the Indian Government endured an acrimonious response from the people of Kashmir. After de-operationalizing Article 370, the indigenous constitution of the state of $\mathrm{J} \& \mathrm{~K}$ was rendered inoperative, although some legislations were retained by the Indian government in its newly framed Jammu and Kashmir Reorganization Act of 2019. One such retained Act is the PSA, which the Indian government has used to detain people it perceives as influential in mobilizing the people against the reorganization.

\section{The PSA enables the state}

to impose surveillance in Kashmir, with the aim of subduing the resistance

Analyzing the operationalization of the PSA, it clearly violates the standards of justice as mentioned under several international humanitarian norms such as the International Covenant on Civil and Political Rights, the Universal Declaration of Human Rights, and the Convention against Torture. It denies detainees' various rights such as being informed of the reasons for arrest, access to judicial authority, judicial review, and the right to a fair trial. It maintains provisions biased toward the side of the police, and gives them immunity from prosecution. ${ }^{28}$ This feature promotes injustice and encourages police officials to go to any extent to detain a person under the PSA. In this context, fabricated First Information Reports (FIRs), biased judgements, vague reasons, and unsubstantial evidence are rampant in the PSA dossiers. ${ }^{29}$

While the PSA has come under vocal criticism for being a 'lawless law' by authorizing all kinds of humanitarian and legal abuses, it should also be criticized for its overwhelmingly negative impact on detainees. For instance, children who are released following detention suffer from several mental disorders, including violent outbursts. In addition, feelings of depression, social withdrawal, anxiety, fear, worth- 
In the politically sensitive

Kashmir, the rhetoric of

the "public order" and the

"security of the state" are

being used by the state to gain

legitimacy for its harsh tactics

lessness, etc. are being experienced by detained children who underwent different forms of torture during their detention. The severity of their distress can be evidenced from the statement of one child detained under the PSA: "Now I won't pelt stones, now I want to wear an explosive laden jacket and blow myself up." ${ }^{30}$ Commenting on its barbarity, former union law minister Ram Jethmalani referred to the PSA as "something we have not heard of even in Nazi Germany."31

In addition to the PSA, there are a number of laws which provide a culture of impunity to the Indian army. More specifically, the Jammu and Kashmir Armed Forces Special Powers Act (AFSPA) of $1990^{32}$ encourages and emboldens the Indian army to exercise their power in a brutal way. It is seen as a "symbol of oppression, object of hate and instrument of destruction and highhandedness." ${ }^{33}$ Given the behavior of the Indian military and the police in Kashmir, it can be said that the military institution has maintained a carte blanche. The power of the judiciary has been usurped, which can be affirmed through the fact that military-centric legislation supersedes human-centric legislation such as the Juvenile Justice Act. This critical situation of human rights abuse in Kashmir by the Indian state and state authorities represents the denial of even a semblance of human rights to the people of Kashmir.

\section{Why Detention?}

Considering the brutal behavior of the Indian state and state police authorities, it is important to analyze why the government is relying so heavily on preventive detentions. The police and paramilitary officers enjoy a virtual culture of impunity in the face of gruesome human rights violations, including killings, torture, and enforced disappearances. ${ }^{34}$ To maintain some semblance of legality, the military and police rely on preventive detention. This is equivalent to 'kill the snake and save the stick' strategy. In other words, the state wants to kill or to gain control over the resistance on one hand, and at the same time it wants to present itself as benevolent by feigning democracy. The objective of annihilating the resistance is achieved through a strategy of perpetual imprisonment, which aims to transform the resistance into obedience and docility. The other objective is to escape from outright condemnation as a brutal state and project itself as a democratic country; thus, the use of this lawless law is justified by making it a dispositif for prevention. This is achieved through rhetorical legitimation. Rhetorical legitimation refers to an explanation used by the hegemonic bureaucratic authorities 
to justify their repression, which in this case is perpetrated by using PSA legislation under the façade of maintaining public order.

\section{Making "Docile Bodies"}

Imprisonment is a form of control. ${ }^{35}$ States that either attempt to annex territories or to subdue revolt often utilize imprisonment as a strategy to weaken the will of the people to resist. It does so by not only striking the body, but also by affecting the soul of the detainees. Instead of using physical torture as a primary method, the body is subjected to deprivation, obligation and prohibitions, which can be seen in the form of rigid rules and regulations during imprisonment. The aim is to coerce the detainee to behave in accordance with the ideology of the state. The authorities utilize power to suppress the prisoners, to make them submissive, to compel them to conform and to behave in the way the authorities want.

Foucault describes this control as the interplay of three elements: knowledge, body, and power. The relationship of these variables can be understood through the 'political technology of the body. ${ }^{36}$ It involves operationalization that uses neither violent methods nor terror, but rather involves the use of knowledge (of the body) in such a way as to keep the subjects (i.e. detainees) under control. This involves the subtle approach of watch-their-every-breath, which can be achieved through techniques of surveillance and observation. The detainees are put under surveillance, as in the panopticon. ${ }^{37}$ This instills a consciousness in the detainee that he is being watched always by an authority -creating fear, mistrust and apprehension. This may keep him from exerting his own will, and promote his exhibition of behaviors corresponding to the objective of authority, but it also deepens in him a sense of resentfulness and humiliation.

The PSA enables the state to impose surveillance in Kashmir, with the aim of subduing the resistance. The unnecessary and excessive interference with, and monitoring of, detainees by police and military personnel even after their release from prison, makes detainees continue to exist in virtual confinement. The surveillance becomes so pervasive that detainees openly claim to experience imprisonment without actually being in prison. Also, their horrific treatment in prison -from forced cohabitation with criminals, to degrading and demeaning treatment inside the jails- is enforced with the intent of establishing Indian authority and making Kashmiri citizens fear.

\section{Rhetorical Legitimization: Making Dispositif for Prevention}

Despite huge criticisms against the PSA law, what has prevented the state and the present Indian dispensation from removing it, even after making the constitution of J\&K inoperative by transforming the region into Union Territory? The first and obvious answer is that the Indian state treats 


\section{Since the Indian state wants}

to eradicate popular support

for their struggle, every

attempt is being made to

discredit and delegitimize the

struggle and movement of

self-determination inherence. Underneath, the objective of the dispositif remains to orient citizens in a way that makes them wellsuited to abide by the government's policies. Therefore, control is being masqueraded as "order and security," and is thus normalized. Hence, the state's rhetorical legitimation provides a justification for the sustained use of this repression.

There is yet another factor which justifies the PSA's use. Hyper-incarceration as a strategy of counterinsurgency is adopted meticulously; because killings or other inhumane procedures would call for widespread condemnation and challenge by anti-colonial constituencies and human rights defenders. Therefore, the state's reliance on relatively subtler tactics, at least in its terminology, aims to justify their action, since such tactics have also been used by anti-colonial powers as well. As argued by Khalili, this can be studied under the framework of liberal counterinsurgency, where the tactics are advertised as more humane, more liberal, and ultimately as a technique for socially engineering the people. ${ }^{38}$

Preventive detention is one of the most severe violations of citizens' rights by a government. It takes away the liberty of an individual based on mere suspicion. Should it be considered legitimate that mere apprehension leads to the forfeiture of one's basic rights? If not, then what makes the persistence of this Draconian law in a supposedly democratic setting? This depends upon the tactics authorities are using to legitimize their actions, 


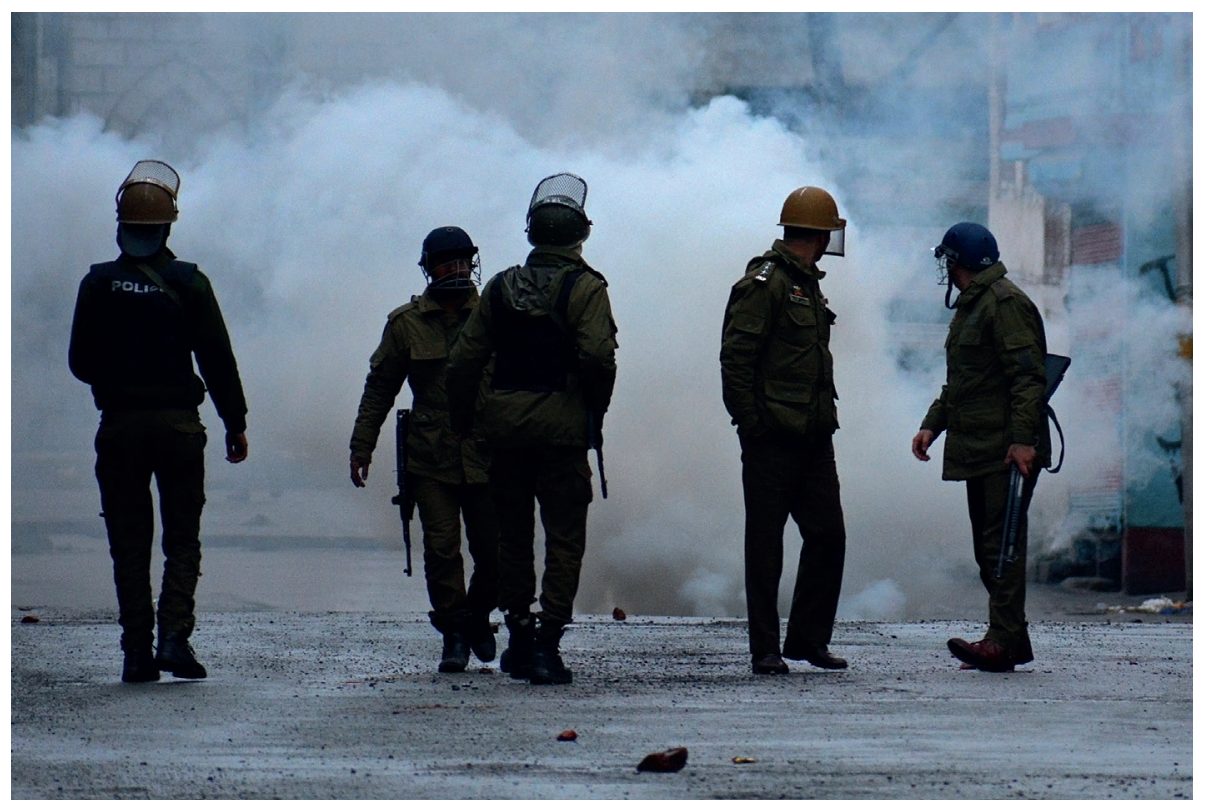

which could be explained how detainees and the Act are perceived and depicted by the police and executive authorities. This can be studied through framing at two levels: the framing of detainees and the framing of the Act.

\section{Framing Detainees}

That the detainees are framed as dangerous by the police and executive authorities is evident from the language used in the police dossiers. This alleged dangerousness provides the police and executive authorities a reason to maintain their brutal behavior. Detainees are described in vague, foreboding accounts and charged with offenses that are beyond their strength and capacity, and thus painted as dreaded criminals. For example, in one of the cases, a minor was described as a "hardcore stone pelter, and an instigator who motivated the youth to throw stones. It was mentioned that he provoked the populace by propagating "anti-national sentiments." For throwing stones against the police/CRPF nafri, he got FIRs registered under sections $147,{ }^{39} 148,149,{ }^{40} 336,307,{ }^{41} 153$-A of

In another case, a person was charged with offenses like raising funds for the terrorist organizations and under sections 307 , and $336^{42}$ of the RPC. The detention order was passed when the detainee was already in custody. Further, the detainee was addressed with negativity as a "goonda (rogue person)." Another dossier highlights a person, a member of the resistance group Tahreek-i-Hurriyat as "venom against the public order." Another dossier represents a person who has been arrested on charges of stone the Ranbir Penal Code (RPC).
Indian police use tear gas to disperse pro-freedom protesters before leaving the site of clashes in Srinagar, Kashmir on March 20, 2019. FAISAL KHAN / AA Photo 
throwing as a "potential terrorist." This points out to the negative framing being done by the police. The dossiers, which do not mention any substantial evidence of terroristic acts or tendencies, label detainees as terrorists merely on throwing stones, which is a common phenomenon in a conflict zone like Kashmir.

This framing of detainees bears sinister effects which can be studied at two levels. At the judicial level, an exaggerated framing may influence the perception of judicial authorities regarding the detainee, and hence their judgment. At the level of the general populace, it may injure the image of detainees among the populace by associating them with negative attributes and criminal activities, as seen in the dossier alleging that a detainee affiliated with Tahreek-i-Hurriyat "looted cash from petrol pump authorities." Similarly, in another case, the police referred to a 12 year-old boy as "don." Labeling them with such names prompts society to maintain a distance from them. This kind of framing undermines the presumption of innocence and furthers the criminalization of detainees.

In a broader context, the consequences of this framing are not limited to detainees only, and may be extended to those who associate themselves with the Kashmir's struggle for freedom. Since the Indian state wants to eradicate popular support for their struggle, every attempt is being made to discredit and delegitimize the struggle and movement of self-determination. In order to diminish the support of the people for the cause, the state uses the tactic of framing to sow mistrust among the people. The purpose is to divide the people and diminish their determined efforts to achieve freedom. The militaristic and oppressive attitude of the Indian authority is an indication that India has, implicitly, understood that neither the land nor the people of Kashmir belongs to it and wants to control it by might.

\section{Framing the Public Safety Act}

Another factor which plays an important role in the implementation and longevity of the PSA is how the now-imprisoned pro-Indian political leadership perceived it and acted upon it. This can be analyzed from how the PSA is being executed and how the pro-Indian political leadership in Kashmir frames it. This goes to the heart of any conflict in which the hegemon co-opts certain personalities for their nefarious purposes. This is exactly what has been done under the PSA.

The New Delhi government has influenced the Act's execution. Prior to the de-operationalization of Article 370, the PSA was a state law. Therefore, although New Delhi had no direct intervention on its execution, India always dictated and patronized the state administration. The Indian government pressured the state as to whom to detain under the PSA. This is observable in the case of Masarat Alam, a pro-freedom leader in Kashmir. One month after his release in March 2015 after four and half years, he was re-ar- 
rested and booked under the PSA, which was invoked under the influence of New Delhi. It was only after the then Indian Home Minister, Rajnath Singh's overnight addition of charges of waging war against the country and charges related to sedition were included, which led to Alam's re-arrest. ${ }^{43}$ In addition, the Chief Minister in 2013 subtly reiterated in the legislative assembly that the state administration had no free will in state affairs but was influenced by the dictates from New Delhi. He related himself with a "daily wager," which shows his state of powerlessness. ${ }^{44}$

Legal luminaries, activists, and human rights organizations decry the PSA as a "Draconian law," 45 "patently, manifestly, and demonstrably unconstitutional, ${ }^{46}$ a "political weapon," and a "weapon of collective state violence." ${ }^{47}$ In contrast, the pro-India political leadership in Kashmir has defended using the PSA. During his tenure as Chief Minister in Kashmir, Omar Abdullah maintained, "The Act has sufficient inbuilt safeguards including reference to an advisory board set up under the Act to confirm or recommend revocation of the detention order leaving no scope for its misuse or arbitrary application by any authority." ${ }^{48} \mathrm{He}$ thus endorsed its existence as mandatory and rejected the demand for its revocation.

Not surprisingly, the Advisory Board which Omar Abdullah touted to defend the PSA is almost non-functional. This can be gauged from the fact that between April 2016 and mid-December 2017, the state government re-

\section{The attitude the Indian state}

maintains against Kashmir and its dealing with the Kashmiris is brutal and unconstitutional

ferred 1,004 detention orders to the advisory board, and the board approved 99.40 percent of the cases. 81 percent of the cases that the board had upheld were unable to withstand challenges in court and were quashed. ${ }^{49}$

It is also important to mention how the people of Kashmir see their treatment and framing by state officials. Generally, the Kashmiris assess this situation as an institutional denial of justice, where state accountability has vanished. The pro-military laws such as JKPSA and AFSPA, which provide a culture of impunity, are seen merely as a means to concretize the military occupation in Kashmir. ${ }^{50}$ This has resulted in eroding faith in institutions, making people reluctant to seek justice from the Indian judiciary. ${ }^{51} \mathrm{As}$ a result, many people avoid the formal judiciary or, if they are already involved, they usually ask the judiciary to setup commissions so as to expose these institutions of the violence and institutionalized denial. ${ }^{52}$

\section{Conclusion}

This paper has discussed how the law had been used as a counterinsurgency tool in the disputed state of Jammu and Kashmir. It offers an explanation 
of how a state can manipulate the judicial mechanism to achieve its own ends. In this case, the Indian state has exploited the PSA to silence dissenting voices.

The PSA has been used as a means to control the resistance and political dissent in Kashmir. In order to achieve this objective, state authorities have become so abusive that whosoever rises up is being detained under this Act, without the protection of any ethical or moral standards. This shows how the state can act without giving any due consideration of, or adherence to, the norms of justice. Detainees are barred from any of the provisions as enshrined in the international law. The only motive behind this state of lawlessness is to neutralize the resistance at any cost.

Although this law has sparked widespread criticism from human rights organizations, nothing concrete has been done to check its arbitrary use. This indicates the lack of political will by the authorities and their intent to utilize the PSA as a crutch to achieve their political motives and interests. This act has been framed in such a way that provides the authorities with the legitimacy to perpetuate its sustained use.

If the application of the PSA is considered vis-à-vis the recent event of revoking Article 370 through a presidential decree, India's sleight of hand is revealed. Now, the Indian government gains direct control in Jammu and Kashmir after de-operationalizing the indigenous constitution of
Jammu and Kashmir, but the Draconian laws that were functional prior to de-operationalization were kept intact with the aim to control the space of dissent. This unilateral move of abrogation of Article 370 was considered unconstitutional by many legal luminaries and activists and the Indian government feared resistance by the Kashmiris. To prevent widespread resistance from happening, 4,000 detentions were made in just two weeks, ${ }^{53}$ which include even members of the pro-Indian political leadership. ${ }^{54}$

The attitude the Indian state maintains against Kashmir and its dealing with the Kashmiris is brutal and unconstitutional. It reveals that India does not care about abiding by its own constitutional law, let alone the international law and humanitarian norms of justice.

\section{Endnotes}

1. C. B. Dhakal, "Understanding Counterinsurgency in Democratic Settings: Counterinsurgency Success and Failure in Kashmir and $\mathrm{Ne}-$ pal," Master's Thesis, Naval Postgraduate School, 2014, retrieved from https://calhoun.nps.edu/ handle/10945/41368.

2. This operation was launched in 1993 to flush out the militants from Sopore, a town in Kashmir.

3. Operation Vijay was launched to drive back the invaders and regain territory in the Kargil sector, while Operation Eraze was launched to capture insurgents in the Northern part of Kashmir.

4. This was launched in 2001; it involves an increased concentration of military along the LOC to prevent infiltration and logistic support from Pakistan to militants in Kashmir.

5. David Galula, Counterinsurgency Warfare: Theory and Practice, (Connecticut: Praeger Security International, 2006).

6. The support provided to the militants can be gauged by the number of people participating in funerals, providing shelter to militants in their 
homes, and other cultural activities which involve celebrating the arrival of militants returning from Azad Kashmir.

7. This term is used by Balraj Puri (1993), referring to the massive support and participation of civilians in the insurgency in Kashmir.

8. Gautam Navlakha, "State Cultivation of Amarnath Yatra," Economic and Political Weekly, Vol. 43, No. 30 (July 26, 2008), retrieved from https:// www.epw.in/journal/2008/30/commentary/ state-cultivation-amarnath-yatra.html.

9. Kashmir, prior to de-operationalization of Article 370 had a special status which made the Indian constitution in the State of Jammu and Kashmir non-applicable. The special status would bar any non-resident of Kashmir to hold property in Kashmir. SASB was an outside entity and could not get a permanent land in Kashmir, hence termed as illegal transfer of land.

10. Haley Duschinski and Shrimoyee Nandihi Ghosh, "Constituting the Occupation: Preventive Detention and Permanent Emergency in Kashmir," The Journal of Legal Pluralism and Unofficial Law, Vol. 29, No. 3 (2017), pp. 314-337.

11. See, Jammu and Kashmir Public Service Commission (JKPSA), (1978) Sec.18 (1/b) and Sec.18 (1/a).

12. Ruchika Bhaskar and Juri Srivastava, "An Unpublicized War: A Critical Analysis of the Public Safety Act and Its Aftermath on the Detainees of Jammu and Kashmir," World Journal of Jurist Polity, (August, 2016).

13. S. D. Muni (ed.), Responding to Terrorism in South Asia, (New Delhi: Manohar Publishers 2006).

14. "India: A 'Lawless Law': Detentions Under the Jammu and Kashmir Public Safety Act," Amnesty International, (March 21, 2011), retrieved from https://www.amnesty.org/en/documents/ ASA20/001/2011/en/.

15. In a response to an RTI filed by Mannan Bukhari, and the same was procured from him.

16. "Lawless Law," Amnesty International, p. 13.

17. Press Trust of India, "Jammu and Kashmir Government Booked 1,332 Persons Under Public Safety Act in 3 years," The Economic Times, (March 29, 2012), retrieved from https://economictimes. indiatimes.com/news/politics-and-nation/jammu-and-kashmir-government-booked-1332-persons-under-public-safety-act-in-3-years/articleshow/12453831.cms?from $=$ mdr.

18. Azaan Javaid, "Kashmir's Infamous Prisons Are Destroying the State's Troubled Youth," Huffpost, (October 25, 2018), retrieved from https://www. huffingtonpost.in/2018/10/24/in-kashmir-not- enough-attention-is-paid-to-what-happens-toyoung-men-after-a-stint-in-jail_a_23570671/? ncid=yhpf.

19. Shaswati Das, "Yasin Malik's Jammu and Kashmir Liberation Front banned," liveMint, (March 22, 2019), retrieved from https://www.livemint.com/ news/india/yasin-malik-s-jammu-kashmir-liberation-front-jklf-banned-1553261458535.html.

20. Khalid Gul, "20-Year Old Bijbehara Boy Booked under PSA," Greater Kashmir, (March 22, 2019), retrieved from https://www.greaterkashmir.com/ news/kashmir/20-year-old-bijbehara-boybooked-under-psa/.

21. Mohammad Owais Gurkoo, "More Than 1000 Minors Booked Under PSA in Kashmir," The Kashmir Walla, (May 9, 2013), retrieved from https:// thekashmirwalla.com/2013/05/more-than-1000minors-booked-under-psa-in-kashmir/.

22. Juveniles of Jammu and Kashmir: Unequal before the Law and Denied Justice in Custody, (New Delhi:Asian Centre for Human Rights, November 16, 2011).

23. Terrorized: Impact of Violence on the Children of Jammu and Kashmir, (Jammu and Kashmir: JKCCS, 2018).

24. Khalid Gul, "Minor Son Lodged in Kathua Jail, Father Sans Resources to See Him," Greater Kashmir, (September 29, 2016), retrieved from https:// www.greaterkashmir.com/news/kashmir/minorson-lodged-in-kathua-jail-father-sans-resourceto-see-him/229644.html

25. "Estimated 13,000 Boys Arrested in Kashmir since India's Crackdown," TRT World, (September 27, 2019), retrieved from https://www.trtworld. com/asia/estimated-13-000-boys-arrested-inkashmirsince-india-s-crackdown-30168.

26. Fayaz Wani, "Specially Abled Youth Booked for Stone Pelting in Kashmir," The New Indian Express, (December 3, 2017), retrieved from http://www. newindianexpress.com/nation/2017/dec/03/specially-abled-youth-booked-forstone-pelting-bypolice-in-kashmir-1717582.html.

27. "Public Safety Act in JK Not to Be Revoked: Omar Abdulla," The Economic Times, (October 1, 2013), retrieved from https://economictimes.indiatimes.com/news/politics-and-nation/publicsafety-act-in-jk-not-to-be-revoked-omar-abdullah/articleshow/23366348.cms?from $=$ mdr.

\section{See Sec. 22 of JKPSA, 1978.}

29. Gaurav Bhawani, "Rule of the 'Lawless Law': Detentions under the Public Safety Act in Kashmir," Economic and Political Weekly, Vol. 53, No. 20, (May 19, 2018), pp. 36-41, retrieved from https:// www.epw.in/journal/2018/20/insight/rule\%E2\%80\%98lawless-law\%E2\%80\%99.html. 
30. Dilnaz Boga, "No Juvenile Courts in J\&K," Infochange, (December, 2009), retrieved from http:// infochangeindia.org/children/172-children/ features/8088-no-juvenile-courts-in-jak.

31. "Ram Jethmalani's Committee Keeps Date with Controversies in Kashmir," The Economic Times, (August 9, 2012), retrieved from.https:// economictimes.indiatimes.com/news/politics-and-nation/ram-jethmalanis-committeekeeps-date-with-controversies-in-kashmir/articleshow/15425630.cms?from $=\mathrm{mdr}$.

32. This act provides armed forces special powers in a "disturbed area." The security officials have power to enter and search a place without warrant; stop, search, and seize any vehicle or vessel which may be suspected of containing any arms, ammunition, or explosives. This military privilege safeguarded by the impunity law is exploited which could be seen through a number of infamous incidents that the Indian army was engaged in such as the Pathribal fake encounter, the Chattisinghpora massacre, the Machilthe fake encounter, and the Kunan-Poshpora mass gang rape.

33. Devyani Srivastava, "Rights-Based Critique of AFSPA," in Vivek Chadha (ed.), Armed Forces Special Powers Act the Debate, (New Delhi: Lancer's Books, 2012), p. 65.

34. Parvez Imroz, et al., Alleged Perpetrators: Stories of Impunity in Jammu and Kashmir, (Jammu and Kashmir: IPTK and APDP, 2012).

35. Michel Foucault, Discipline and Punish: The Birth of the Prison, translated by Alan Sheridan, (New Delhi: Penguin Books, 1991).

36. Foucault, Discipline and Punish, pp. 24-26.

37. Foucault, Discipline and Punish, pp. 200-201.

38. Laleh Khalili, Time in the Shadows: Confinement in Counterinsurgencies, (Stanford: Stanford University Press, 2013).

39. This provision is related to punishment for rioting.

40. This section of the RPC provides that "If an offence is committed by any member of an unlawful assembly in prosecution of the common object of that assembly, or such as the members of that assembly knew to be likely to be committed in prosecution of that object, every person who, at the time of the committing of that offence, is a member of the same assembly, is guilty of that offence."

41. This section is related to attempted murder.

42. Act of endangering the life or personal safety of others.

43. "Sedition Will Not be Forgiven, Masarat Will Go to Jail: Rajnath," India Today, (April 17, 2015), retrieved from https://www.indiatoday.in/india/ story/srinagar-protests-masarat-alam-will-go-tojail-says-rajnath-singh-249081-2015-04-17.

44. "Omar Abdullah's Emotional Speech in the Assembly on the Death of a Young Boy in Baramulla," National Conference Media Cell, retrieved on November 13, 2019, from https://www.youtube. com/watch?v=s2FV4akxuL0.

45. "Lawless Law," Amnesty International.

46. A. G. Noorani, as cited in Freny Manecksha, "The Public Safety Act Is a Political Weapon for the Government in Kashmir," The Wire, (December 28, 2016), retrieved from https://thewire.in/ government/public-safety-act-kashmir.

47. Shrimoyee Nandini Ghosh, "The Public Safety Act Is a Political Weapon for the Government in Kashmir," Kashmir Ink, (March 1, 2017), retrieved from http://www.kashmirink.in/news/perspective/understanding-public-safety-act-psa--aweapon-of-collective-state-violence/289.html.

48. Press Trust of India, "Act Not to be Revoked," Greater Kashmir News, (March 14, 2015), retrieved October 1, 2019, from https://www. greaterkashmir.com/news/more/news/act-notto-be-revoked.

49. Venkatesh Nayak and Shaikh Ghulam Rasool, "RTI Reveals Advisory Board Under J\&K Public Safety Act Spent 75\% Of Its Budget Upholding Detention Orders Which J\&K High Court Quashed Later On" Commonwealth Human Rights Initiative, (August 2, 2018), retrieved from https://www.humanrightsinitiative.org/blog/rti-reveals-advisoryboard-under-jk-public-safety-act-spent-75-of-itsbudget-upholding-detention-orders-which-jkhigh-court-quashed-later-on.

50. Haley Duschinski and Bruce Hoffman, "Everyday Violence, Institutional Denial and Struggles for Justice in Kashmir," Race and Class, Vol. 52, No. 4 (2011), pp. 44-70.

51. Shazia Ahad, et al., Torture: Indian State's Instrument of Control in Indian Administered Jammu and Kashmir, (Jammu and Kashmir: IPTK and APDP: 2019), p. 14.

52. Duschinski and Hoffman, "Everyday Violence."

53. "Kashmir: 4,000 People Arrested Since August 5 Says Report," Huffington Post, (August 19, 2019), retrieved from https://www.huffingtonpost.in/ entry/kashmir-4000-people-arrested-august5-saysreport_in 5d5a54e6e4b056fafd0e25e9.

54. Muzamil Jaleel, "Three Weeks On: Politics Vacuum in Kashmir Valley, Little Sympathy on Street," Indian Express, August 26, 2019, retrieved from https://indianexpress.com/article/india/jammukashmir-article-370-mehbooba-mufti-omar-abdullah-army-amit-shah-bjp-5936605/. 

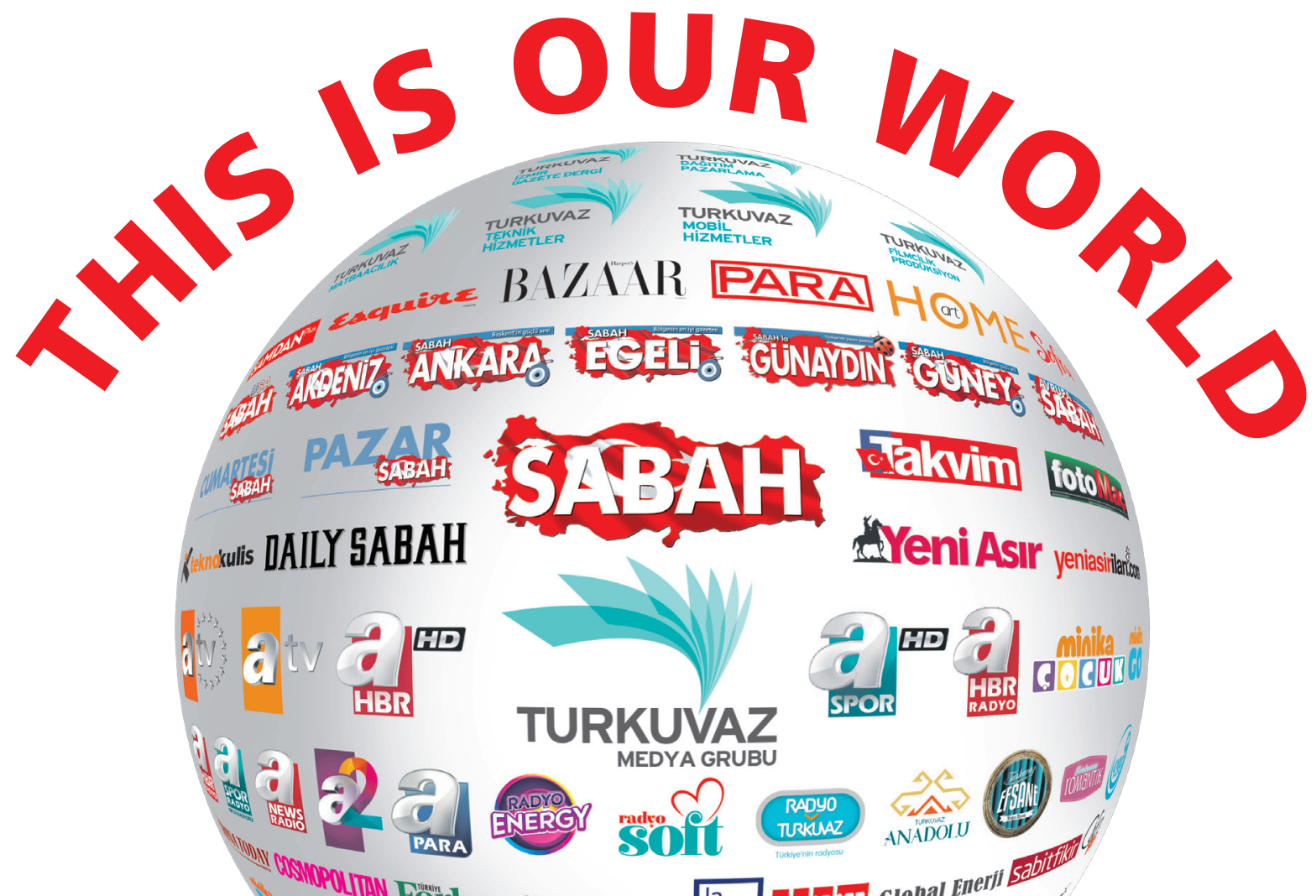

Turkuvaz Media Group is the leading group of companies which deals with broadcasting, publishing and distribution activities in Turkey. Most reputable national and international magazines, best selling local and national newspapers and prestigious tv channels create the most powerful synergy in Turkish media.

The opportunity to utilize this power for your advertisements is in your hands. Why not use it? 